\title{
Imperfect Sporangia in certain Pteridophytes. Are they vestigial?
}

\author{
BY \\ F. O. BOWER, Sc.D., F.R.S., \\ Regius Professor of Botany in the University of Glasgow.
}

TMPERECTLY developed parts have played an im1 portant rồle in arguments on Evolution. On the zoological side especially they have been used as weighty evidence. Similarly, on the botanical side they have been the basis of discussion: in the morphology of the flower, abortive stamens, carpels, pollen-sacs, and ovules have been cited as foundations for elaborate comparative argument. For instance, where present in normal-position the existence of an abortive stamen, or staminode, has been accepted as sufficient indication of the previous existence of a fully developed stamen in the ancestral line; and on such evidence natural affinities have been traced and accepted, usually without question.

But floral morphology has gone further: comparative study has led to the conclusion that in certain ancestral lines of descent parts have existed, which in the descendants of the present day are entirely unrepresented by any vestigial growth. This condition of complete disappearance of a part or parts has been styled 'ablast,' as distinct from 'abortion,' where the incompletely developed part has an objective existence $^{1}$. Against the former, as a fiction of Comparative

1 These distinctive terms were introduced by Schmitz (Hanstein's Bot. Abhandl., Bd. ii, Heft I, p. 5i).

[Annals of Botany, Vol. XV. No. LVIII. June, 19or.] 


\section{Bower.-Imperfect Sporangia in certain}

Morphology, Wigand raised an anti-evolutionary protest ${ }^{\mathbf{1}}$, maintaining that an essential difference exists between the two, and that 'ablast' exists only in the imagination, as a consequence of the assumption of unity of type in large groups of plants. It is doubtless salutary that such protests should be made, and they should have the effect of checking the exuberance of those who would extend a 'Type-method' beyond due limits, in the study of living forms. Fortunately there is now less need for such warnings than in the early seventies, the present tendency being towards broader polyphyletic views.

At the time of its issue Wigand's protest was suitably met by Eichler, who maintained that the conditions distinguished as 'abort' and 'ablast' are not essentially different in kind, but only differ in degree. He points out that abortion itself is not susceptible of objective proof: 'objectively we see nothing more than that cell-divisions occur, that a rudiment appears; thus strictly speaking we observe that something develops, not that something is reduced. This may become a gland, an emergence, or what not. It is comparison, and usually the comparison with other species and genera, \&c.that is, the type-method-which teaches that it is a reduced organ, and what is its special category. Whenever the same comparative method leads even to the assumption of a complete suppression, where no rudiment of the organ is seen with the bodily eye, in my opinion that is, in point of fact, no more than one step further along the same course ${ }^{2}$ '. This is the position which, within suitable limits, is at the foundation of the current view as to abortion of parts within the Angiospermic flower, and it is extended also to the vegetative organs.

The discussion above quoted related in the first place to parts such as stamens and carpels. But the same arguments are also applicable to individual sporangia. As an example,

1 Darwinismus, i, p. 444. 'Der Abortus nach der Typen-Methode und nach der Descendenz-Theorie.'

${ }^{2}$ Eichler, Bliithendiagramme, p. $5^{2}$. 
the abortive ovules in the carpels of the Clematideae may be mentioned; though in the mature state only one ovule is found fully developed in each carpel, several are initiated in position corresponding to those of the Helleboreae; on these facts the argument may be based that a plurality of ovules was more widely the rule in the ancestors of the Ranunculaceae than it is at the present day ${ }^{1}$. A similar case as regards the pollen-sacs is found in the stamens of Salvia. There is thus no reason to restrict the method to axes, leaves, and so forth, but it may be, and has been, applied to sporangia equally with other parts.

In the Pteridophytes, too little attention has hitherto been paid to such subjects, and notably observations of arrest of the spore-producing parts have been neglected. It is the comparative isolation of many of the genera, and the paucity of species in some of the most important of them, which has stood in the way of arguments from arrest taking their proper place in the morphology of the Pteridophyta. But the argument to be based on an imperfect sporangium of $L y c o-$ podium, or the abortive fertile spike of an Ophioglossum, seated in the position normal in other individuals, species, or allied genera, for a fully matured one, is precisely the same as that on an imperfect stamen or carpel, pollen-sac, or ovule. Further, a comparison as regards the presence or absence of spore-producing parts, in species evidently related to one another, may lead to the conclusion that sporangia, entirely unrepresented at the present day, were probably present in the ancestry; the line of argument being the same as that in the cases of hypothetical 'ablast,' or complete suppression of floral parts.

In this paper I propose to bring together certain cases of incompletely developed sporangia, or spore-producing parts in the Pteridophyta, in order that those facts may have their due weight in the general discussion of the balance of the vegetative and fertile regions of the primitive leafy sporo-

1 Eichler, Blüthendiagramme, p. I74; also Prantl, Engler's Jahrbücher, vol. ix, p. 237 . 
phyte. The cases quoted are chiefly from among the ClubMosses, in which the problem is more readily handled than in most other Pteridophyta.

\section{Phylloglossum.}

I have already drawn attention to the fact that the transition from the protophylls of this plant to the sporophylls is usually abrupt ${ }^{1}$. Occasionally the last of the protophylls to be formed is smaller than the rest, and thus it approaches in size to the normal sporophyll. But Mettenius ${ }^{2}$ states that sometimes the fertile shaft bears a sterile bract some small distance below the strobilus. In my own specimens, in one case, a sporophyll of larger size than usual, with a sporangium attached, was found isolated below the strobilus ${ }^{3}$ : thus there are indications of a transition between the protophylls and the sporophylls. In the strobilus itself all the lower sporophylls bear sporangia; Bertrand remarks, however ${ }^{4}$, that though this is the case for the three lowest whorls of the spike, the sporangia on the fourth whorl are not always fully developed, those of the fifth whorl are atrophied, while those of the sixth bear but vague traces of sporangia: such sporangia may appear only as slight convexities of the surface, while still higher all traces may be absent. Mettenius also noted that the sporophylls at the apex of the strobilus may be sterile.

I have seen such abortive sporangia in the apical region of the strobilus of Phylloglossum; I doubt, however, any numerical constancy of those fully formed, for I have seen sections of a strobilus in which the leaves of the fourth whorl were without any trace of a sporangium.

It is thus seen that while there is in Phylloglossum as yet no detailed evidence of abortion of sporangia at the base of the strobilus, or in connexion with the protophylls, still occasionally there are intermediate types between the proto-

1 Studies, i, p. 506.

3 Loc. cit., Pl. xliii, Fig. 22.

${ }^{2}$ Bot. Zeit., I 867 , p. 99 .

4 Archives Bot. du Nord, vol. ii, pp. 83 , I 27 . 
phylls and the sporophylls. But abortion, partial or complete, does take place at the apex. It will be a matter for subsequent discussion what is the comparative bearing of these facts.

\section{LYCOPODIUM.}

This genus was divided by Spring ${ }^{1}$ according to the distribution of the sporangia, an arrangement which is maintained, with amendments, by Baker in his Fern-Allies ${ }^{2}$. In dealing with the abortion of sporangia, and their distribution upon the plant, I shall follow Baker's arrangement, giving, in the order of the species in his work, the details which I have thought worthy of note for the present purpose, after looking through the herbaria of $\mathrm{Kew}$, and of Glasgow University.

By adopting for the present purpose Baker's arrangement, I do not deny that it is open to such amendments as have been proposed elsewhere ${ }^{3}$.

\section{Sub-genus. Selago.}

\section{Group of $L$. Selago.}

I. L. compactum, Hook. Old sporangia were observed at the leafbases, even down to the base of large plants. How early does this fertility begin in the individual?

3. L. Selago, L. There is usually a sterile region at the base of the plant: this is followed by the well-known alternating fertile and sterile zones. About the limits of these zones, sporangia of smaller size are found, which sometimes remain closed when all those in the neighbourhood have dehisced. There is no marked change of size or form of leaf, on passing from the sterile to the fertile zones. Occasionally a single sporangium may be found in an otherwise sterile region.

6. L. erythraeum, Spring. A long sterile basal region is found in some specimens.

1 Monographie des Lycopodiacées, p. 18.

2 Handbook of the Fern-Allies, I 887, p. 8.

3 Engler and Prantl, Pflanzenfamilien, i, 4, p. 591. 


\section{Bower.-Imperfect Sporangia in certain}

7. L. Saururus, Lam. There is usually a sterile basal region of some length; no obvious external distinction of sterile and fertile regions.

9. L. Hamiltonii, Spreng. (incl. L. vernicosum, H. \& G.). Plants from Khasia (C. B. Clarke) show transition from sterile to fertile region very gradually as regards leaf-form; at most there is a gradual and ultimate diminution of size. Occasional single sporangia may be found far down in the sterile region, in the axil of leaves of the larger sterile type. This has been seen in many other specimens besides Clarke's Khasia plants.

I I. L. reflexum, Lam. As in L. Hamiltonii, isolated sporangia were found in the lower sterile region.

I2. L. miniatum, Spring. The same.

I3. L. ceylanicum, Spring. The same.

I4. L. lucidulum, Michx. No distinction of sterile and fertile zones: sometimes the fertile zone is very short; in some cases a single isolated sporangium is found in a sterile zone. The external differentiation of sterile and fertile zones is feeble.

16. L. serratum, Thunb. The foliage leaves of this species are unusually large. The size of the sporophyll varies: it may be fully the size of the foliage leaf, or it may be a mere tooth, subtending the large sporangium: but there is no obvious balance between the size of the sporangium and that of the sporophyll. This all shows that the larger size of the leaf does not necessarily depend on its being sterile; but usually the sporophylls are smaller than the foliage leaves, and this is specially the case at the upper limit of the fertile zones.

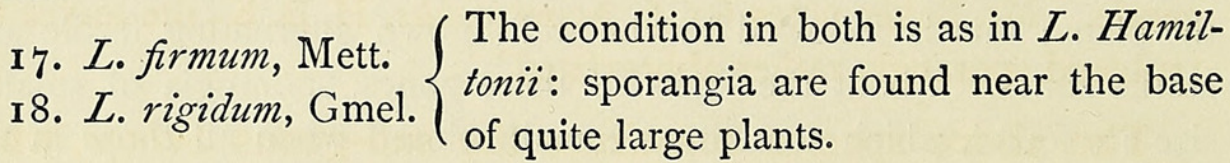

\section{Group of L. taxifolium.}

20. L. fontinaloides, Spring. Alternating sterile and fertile zones without external differentiation, and of varying length.

2I. L. tetragonum, H. \& G. Usually sterile below, but after the transition, without change of form of shoot, the fertile form of shoot is maintained.

22. L. myrsinites, Lam. Alternating sterile and fertile zones: isolated sporangia found here and there in the sterile region. 


\section{Pteridophytes. Are they vestigial?}

25. L. verticillatum, Linn. fil. One of the least differentiated species, as regards sterile and fertile zones: there is no distinction between sterile leaves and sporophylls, while isolated sporangia are dotted here and there in the sterile region. In extreme cases there is no distinct fertile region at all, but only isolated sporangia among sterile leaves.

$\left.\begin{array}{l}\text { 27. L. setaceum, Hamilt. } \\ \text { 28. L. mollicomum, Mart. }\end{array}\right\}$ Alternating sterile and fertile zones.

3o. L. affine, H. \& G.

$\left.3^{\text {r. L. Lindeni, Spring. }}\right\}$ Alternating sterile and fertile zones.

32. L. attenuatum, Spring.

35. L. Trencilla, Sodiro. This 'giant of recent Lycopodiaceous types' shows, in the Kew specimens, sporangia down to its very base: there is no differentiated strobilus.

36. L. sarmentosum, Spring. $\left\{\begin{array}{l}\text { Alternating sterile and fertile zones, } \\ \text { usually with a sterile region at the } \\ \text { 37. L. linifolium, L. }\end{array}\right.$ base: some isolated sporangia in the
sterile regions.

38. L. dichotomum, Jacq. There is usually a long sterile basal region: the sterile and fertile leaves are alike; the fertile zones are irregular : a few sterile leaves may intervene in a fertile zone, and isolated sporangia may be found in a sterile zone. At the limits abortive sporangia have been seen.

39. L. taxifolium, Swartz. There is a long sterile region at the base of the plant: above it alternating sterile and fertile zones : there is a tendency to fine off at the fertile apices, forming ill-defined terminal strobili, with smaller leaves: but the graduation is very slight and gentle. Mr. Baker notes for $L$. passerinoides, H. B. K., the leaves that 'subtend sporangia rather abbreviated.'

The above species constitute the sub-genus Selago, which includes mostly ground-growing plants: the characters are based on the sporangia being 'placed in the axils of unaltered leaves all down the stem ${ }^{1}$.' The following are the most important points brought out in the above notes:-

I. Most species have a sterile basal region of considerable length: but sporangia have been observed down to the base of the mature plant, in $L$. compactum, and Trencilla, or close

\footnotetext{
${ }^{1}$ Baker, Fern-Allies, p. 8.
} 


\section{Bower.-Imperfect Sporangia in certain}

to the base in others, e.g. $L$. firmum and rigidum. There are, however, no records for young states of these species.

2. The sterile and fertile zones are imperfectly differentiated: this is illustrated by all the species.

3. The sterile and fertile leaves are mostly alike: and though the fertile leaves show in some cases a smaller average size than the sterile ( $L$. serratum), this is not constantly the case even in that species.

4. Isolated sporangia have been frequently found in the otherwise sterile region, in the axils of leaves resembling the sterile leaves in size (L. Selago, Hamiltonii, reflexum, miniatum, ceylanicum, lucidulum, myrsinites, verticillatum, setaceum, mollicomum, sarmentosum, linifolium, dichotomum).

5. Sterile leaves have been found in the fertile zone $(L$. dichotomum).

6. Incompletely developed sporangia have been found at the limits of the fertile zones in L. Selago, and dichotomum: this is not readily observed in herbarium specimens, and most of the species have only been available in the dry state.

It is clear from these facts that the fertile and sterile regions are, in the sub-genus Selago, very imperfectly differentiated, a conclusion which has important bearings on any view as to the evolution of the genus.

\section{Sub-genus II. Sub-Selago.}

42. $L$. carinatum, Desv. The foliage leaves graduate by gentle steps to the sporophylls: the spike is terminal but not distinctly defined, and the lower limit of sporangia is not sharply marked. Straggling sporangia, and sporangia of smaller size, i.e. partially abortive, are found at the base of the spike. Occasional reversions from the strobilus to the sterile state have been seen in this species, a condition similar to that in the Selago group.

45. L. gnidioides, L. fil. The delimitation of the strobilus in this species is by no means exact : interruptions of the fertile zone occur at the base, and isolated sporangia are frequent, irregularly scattered in the sterile region below. The strobili often resume a vegetative condition at the apex. 
In some Madagascan forms of this species there is a basal rosette of larger foliage leaves, from which springs at once the rather definitebranched strobilus condition, suggesting a comparison with Phylloglossum.

46. L. dacrydioides, Baker. The basal limit of the strobilus is illdefined.

47. L. squarrosum, Forst. There is a specialization of the strobilus from below upward, as shown by the very gradual decrease in size of the sporophylls: at the base these equal the sterile leaves in size. The base of the fertile zone is not always sharply limited; occasionally isolated sporangia may be found below, in the sterile zone.

49. L. Dalhousiaeanum, Spring. There is a considerable difference between foliage leaves and sporophylls, but the transition is gradual : sporangia appear first on the transitional leaves, about half-way between the two types. The strobili are apt to be interrupted by sterile zones, where however the leaves remain small.

The sub-genus Sub-Selago, introduced by Baker into Spring's system, shows the sterile leaves 'a little different from the bracts, but passing into them gradually. Sporangia aggregated into indistinct terminal spikes.' The few species thus grouped show many of the characters of Selago. All have a basal sterile region, but recurrence of sterile and fertile zones is rare, though occasionally seen (L.Dalhousiaeanum): reversion from the fertile strobilus to a sterile state is more frequent (L. carinatum, gnidioides). The progressive diminution of size of the fertile leaves upwards is sometimes gradual (L. squarrosum); this was already indicated in $L$. taxifolium, in the Selago group: it is sometimes more sudden ( $L$. Dalhousiaeanum). Isolated sporangia in the sterile region are more rare, but do occur (L. carinatum, gnidioides, squarrosum): also partially abortive sporangia at the base of the strobilus ( $L$. carinatum). Thus all the characters together show a very close similarity to what is seen in the Selago group, but with gradually increasing definition of the strobilus from the lower vegetative region. 


\section{Bower.-Imperfect Sporangia in certain}

\section{Sub-genus III. Lepidotis.}

\section{Group of $L$. inundatum.}

50. L. inundatum, L. The transition from sterile to fertile leaves is rather sudden, the fertile leaves being slightly smaller, and widened at the base. The basal region of the strobilus shows sporangia abortive in various degrees, some consisting merely of a mass of vegetative cells, containing no spore-mother-cells: these abortive sporangia occupy the normal position, and intermediate steps lead on to the normally developed sporangia above. There is usually no irregularity of the spike in this species : in certain varieties it is very lax in habit, and the spike is carried up on a long stalk (var.pinnatum, Chapm., and Bigelovii, Tuckerm.), a habit suggestive of $L$. alopecuroides.

5I. L. Drummondii, Spring. Specimens in Kew from Baron v. Müller show much elongated and interrupted spikes, with alternating sterile and fertile zones.

52. L. alopecuroides, L. The transition from the vegetative to the fertile region is not abrupt as regards leaf-form: no interruptions observed. In habit like a large $L$. inundatum.

In the inundatum group, which inhabits swampy ground, the differentiation of the strobilus in form is still only slight, while abortive sporangia are found at the base (L.inundatum): $L$. Drummondii even approaches Selago in its alternation of successive sterile and fertile zones.

\section{Group of L. Phlegmaria.}

55. L. nummularifolium, Blume. Fertile spikes may pass again into foliage shoots, and these again to fertile spikes: this seems not uncommon.

56. L. aqualupianum, Spring. Ditto.

6o. L. varium, R. Br. The strobili of this species are apparently well defined, and it is therefore placed in the group of L.Phlegmaria; but Sir J. Hooker's specimen from the Auckland Islands, in the Glasgow herbarium, shows that sporangia of normal size are present far below the apparent limits of the strobilus. The latter are 'subtetragonous,' with broad ovate-acute sporophylls: but the sporangia 
are found also in the axils of large 'foliage leaves' below. This was verified also in other specimens.

6r. L. subulatum, Desv. The condition here is the converse of $L$. varium. The strobili are well defined, their leaves being broad and ovate, while the foliage leaves are lanceolate-acuminate: but the lower part of the strobilus with leaves of the sporophyll-type may have no sporangia, and higher up irregular zones may also be sterile : the apex of the strobilus may revert to the vegetative type of leaf.

62. L. ophioglossoides, Lam. (incl. L. fertile, Baker), shows transitions of the fertile strobilus to the sterile state.

63. L. pinifolium, Blume, ditto.

67. L. Phlegmaria, L. There is a sharp contrast between the large foliage leaves and the small sporophylls, and the transition is usually sudden, though intermediate leaf-types do occur. Usually the strobili are continuously fertile, but at the branchings the first leaves above may be sterile, though of the small sporophyll-type. Transitions from the fertile to the sterile type of shoot, and back to the fertile, are not uncommon.

It is seen from the above notes that though in the Phlegmaria-group, which are epiphytic, the spikes are 'slender, dichotomously forked, with bracts very different from the leaves ', isolated sporangia may be found in the vegetative region ( $L$. varium), and there may occasionally be alternating sterile and fertile zones ( $L$. nummularifolium), while leaves of the sporophyll type may develop no sporangia (L. subulatum, Phlegmaria). Transitions from the fertile strobilus to the larger leaved foliage shoot are frequent (L. nummularifolium, subulatum, ophioglossoides, pinifolium, Phlegmaria). Thus the differentiation of the strobilus is one of external form, rather than a rigid difference of intimate character. The converse conditions of $L$. varium and $L$. subulatum show that the difference in size of sporophylls and foliage leaves is not due directly to correlation in the individual: other cases might be quoted supporting the same conclusion, notably L. serratum. 


\section{Group of L. cermum.}

In the cernumm group of ground-growing species the strobili are clearly defined. Transitions from the strobilus back to the vegetative shoot are decidedly rare: none were observed in $L$. cernum itself, in a very large number of specimens: a slight indication of it was seen in L. obscurum, but none in L. casuarinioides.

\section{Group of L. clavatum.}

These are all terrestrial, with trailing habit, and ascending branches, which bear well-defined strobili : reversions from strobilus to vegetative shoot have not been observed. A comparison of the species illustrates the way in which the strobilus may have come to be lifted on a long pedicel above the ground, with the result of a better dissemination of the spores: this is shown by the following notes.

76. L. Sprucei, Baker. This species having solitary spikes sessile on leafy branches, connects the group with $L$. inundatum.

77. L. magellanicum, Sw., has also spikes 'sessile or nearly so,' and 'often many to the branch,' as in L. clavatum.

8o. L. annotinum, L. The leaves at the base of the strobilus are frequently smaller than either foliage leaves or sporophylls, but they occupy no specially elongated zone: the leafy branches, which rise from the creeping rhizome and bear the strobili, attain a height of six inches.

78. $L$. contiguum, Klotzsch. The zone may be a quarter of an inch in length: the strobilus simple or sometimes branched.

81. L. diaphanum, Sw., has a considerable zone of narrower linear leaves between the strobilus and the larger foliage leaves. The strobilus is simple or branched.

84. L. clavatum, L., has an elongated stalk, of length varying from two to six inches, covered with distant appressed scales, i. e. the axis has lengthened, and the scales are correlatively reduced. L. aristatum, H. B. K., is a form with specially elongated stalk, and several spikes.

86. L. paniculatum, Desv. The stalk, nearly a foot long, may arise direct from the rhizome, and bears many branched spikes. 
In this series of ground-growing forms, the intercalation of a peduncle, with small distant scales, between the largerleaved foliage shoot and the definite strobilus, is indicated. The question whether the peduncle is directly derived from the basal part of the strobilus, or from a specialized part of the already sterile foliage-region, may be left open: but as sporangia are not found on it, nor even any vestiges of arrested sporangia, the latter seems the more probable source of the peduncle. The importance of it in ground-growing forms is obvious.

\section{Group of L. laterale.}

The strobilus is well differentiated from the sterile shoot.

88. $L$. diffusum, R. Br., 'intermediate between $L$. laterale and L. magellanicum ${ }^{1}$ ' After clear cases of dichotomy, the one branch continues sterile growth, the other is fertile.

89. L. laterale, R. Br., the same behaviour of the branches is seen, but more pronounced: sometimes both branches are sterile: in some specimens the successive branches on the same side are fertile, giving a peculiar sympodial effect.

\section{Sub-genus IV. Diphasium.}

The strobilus is well differentiated from the sterile shoot. The peculiarity is in the bilateral development of the latter.

90. L. carolinianum, L. In some forms differs only in minor degree from $L$. clavatum or L. inundatum, as regards leafage ; but some forms, e. g. $L$. sarcocaulon, Welw., show extreme cases of dorsiventrality.

92. $L$. complanatum, L., often regarded as merely a dorsiventral form of $L$. alpinum.

93. L. scariosum, Forst., sometimes shows the strobilus fining off to an attenuated, vegetative apex, but no complete return to the foliage type of shoot.

94. L. volubile, Forst. A highly specialized, scandent, dorsiventral shoot, with definite strobili, which show no return to the vegetative type. 


\section{Bower.-Imperfect Sporangia in certain}

\section{GENERAL THEORETICAL POSITION BASED ON COMPARISON OF THE GENUS LYCOPODIUM, AS REGARDS DISTRIBU- TION OF SPORANGIA.}

The theoretical bearing of such facts as the recurrence of sterile and fertile zones in certain Lycopods, and the existence of abortive sporangia at the limits of the fertile zones, was pointed out in the first part of my studies ${ }^{1}$, and again in a later paper in the Annals ${ }^{2}$. The facts being now amplified by examination of a larger number of species, and of specimens, the conclusions which may be drawn will be stated in an extended form.

First it will be well to re-examine the theoretical position as regards abortive parts generally. It is possible to look upon any imperfectly developed part as either in the up-grade of development - as something nascent; or in the down-grade of development-as something evanescent; and these ideas themselves may be applied in either of two senses, according as they are taken to refer to the individual or to the race. There are thus four possible views which may be taken of any imperfectly developed part:-

(I) that it is nascent in the ontogeny;

(2) that it is evanescent in the ontogeny;

(3) that it is nascent in the phylogeny;

(4) that it is evanescent in the phylogeny.

These distinctions may not be admitted by those who assume that the ontogeny is a direct and complete index of the phylogeny, that the parts first formed in the individual were also the first to appear in the evolution of the race. This ' recapitulation theory' may be consistently entertained for the sporophyte by those who hold that the alternating generations of the Archegoniatae originated by differentiation of homologous phases ${ }^{3}$ : to them the view is possible, though I am not aware of its having been definitely expressed, that spore-production may have been in the evolution a sort of

1 Phil. Trans., I 894, B., p. 535 .

2 Annals of Botany, vol. viii, p. 343 .

3 See Scott, Presidential address to Sec. K, Brit. Assn. Report, I896, p. 996 ; where the necessary literature is quoted. 
afterthought, a mode of propagation taken up by already existent vegetative parts. There is, however, a comparative obstacle to this view: for spore-production is a characteristic of the simplest sporophytes : and if the plants of the past in any degree resembled the plants of the present, spore-production must have been, even on an homologous theory, an early event in evolutionary history. But to those who hold the antithetic theory of alternation, that the sporophyte is the result of amplification of the zygote, and that spore-production was its first end, and was, just as it is now seen to be, a constantly recurring feature throughout descent ${ }^{1}$, a recapitulation theory is plainly inconsistent with their view ${ }^{2}$. For ex hypothesi, in the simplest cases the spore-production preceded the vegetative development of the sporophyte, though in development of the individual, in the more advanced cases, the vegetative system precedes the spore-production.

The question of priority in the history of descent of sporophylls and vegetative leaves cannot then be settled summarily by the statement that the latter appear first in the ontogeny ${ }^{3}$ : neither can it be decided by any detailed comparison of the two leaf-forms as regards individual development ${ }^{4}$ : an hypothesis that the foliage leaf is a sterilized sporophyll is based just as much upon the fact of the similarity of development of the two leaf-forms, as the converse view that the sporophyll is an altered foliage leaf. Nor will the record of an infinity of intermediate forms, half sterile and half fertile ${ }^{5}$, nor the proof that experimentally the sporophyll can be converted into a foliage leaf ${ }^{6}$, carry us any further than to show the intimate relations of the two. These facts do not touch the question of phylogenetic priority.

1 See Bower, Presidential address to Sec. K, Brit. Assn. Report, I898, p. I03 I.

2 This was fully pointed out by me in the Annals, vol, vi, p. 372 .

3 Goebel, Science Progress, I895, p. I 20.

${ }^{4}$ Glück, Flora, I895, Heft 2, p. 383 .

5 Glück, loc. cit., p. 384.

6 Goebel, Annals of Botany, vol. vi, p. 359 ; also Ber. d. Deutsch. Bot. Ges., 1887. Atkinson (Bot. Gaz., vol. xxii, p. 220) made similar experiments, and from similar results finds the converse view to be still tenable. 


\section{Bower.-Imperfect Sporangia in certain}

But a valuable clue for decision of the case for the leafy sporophyte is derived from the analogy of the simpler Bryophytes. The sporogonium of Riccia, with no seta, is currently accepted as the most primitive type ${ }^{1}$. A comparison of successively more complex types indicates the intercalation of a vegetative phase, the seta, before the spores are formed. The same is the case in other Bryophyta, and even in Mosses where the seta often produces a considerable vegetative development for nutritive ends. Are we to assume in these cases that the vegetative seta, because it precedes the capsule in origin in the individual, preceded it also in the phylogeny? We can only conclude from their comparative study that spore-p"oduction, which is the constant feature in them all, has been deferred, by a later intercalated phase. If that be so, then the order of appearance of the parts of the individual sporogonium is not an index of the order of their appearance in the history of the race.

The same argument will hold for the whole plant of a $L y c o$ podium, and an interesting analogy is to be traced between the successive vegetative and fertile phases of a Bryophyte sporogonium, and of a simple Lycopod. In such a Moss as Funaria or Polytrichum, the archesporium appears in longitudinal sections of young sporogonia, as a definite row of cells on either side of the columella. It is impossible at first to tell in those rows of cells the exact limit where sporedevelopment will actually begin. Below that point the cells of the row develop sterile, above it fertile; but in either case the segmentations which lead to them are the same. Passing to the apex, the archesporial row is continued beyond the extreme limit of fertility; structurally the possibility of further spore-production seems to be there, but arrested. In the Lycopod a similar succession of phases is seen, but complicated by the fact that appendicular organs are borne: the lower sterile region may be compared as regards its physiological condition with the seta, though here more

${ }_{1}$ Goebel, Organographie, ii, pp. 321, 328. 
definitely nutritive in function ${ }^{1}$ : the strobilus with the sporogonium: the abortive sporangia at the base with the arrested archesporial region at the base of the capsule: the abortive sporangia so commonly found at the apex of the strobilus with the arrested archesporial region, which passes upwards into the operculum. There is first in each case a vegetative phase, which is nutritive; this merges into a fertile phase, which again is arrested above, being probably in each case limited by nutritive supply. On the antithetic theory, in either case the spore-production was the prior function in the race; in either case that function was delayed in the individual by a later intercalated vegetative phase. The prevailing view which regards the evolution of the sporophyte in the two great series of the Archegoniatae as following from the very first a distinct course of development is probably correct, in the sense that specialized Bryophyte sporogonia did not give rise to Pteridophyta; but the analogies as regards balance of the vegetative and spore-bearing phases should not be lost sight of, on the superficial ground that appendicular organs are present in the one and not in the other. For both series have equally been subject to the fundamental laws of nutrition, which have dictated these successive phases.

Our first duty will then be to interpret those parts which are found about the transition from the vegetative to the fertile region in Lycopodium, and see what bearing they may have on our views of the origin of the vegetative region in that genus. But in doing so we shall start with the clear understanding that though certain parts are formed first in the

\footnotetext{
${ }^{1}$ It seems hardly necessary to state that no exact morphological homology is here implied, but merely a comparison of the successive phases of nutrition and spore-formation. The specialized sporogonium of a Moss is not looked upon as the progenitor of any race of vascular plants. As I have been credited in various quarters, and on insufficient grounds, sometimes quite misunderstood, with the opinion that a Moss sporogonium was the source from which a leafy sporophyte originated, I wish to expressly disown such an opinion. A parallelism in method of morphological advance may be traced, without any recognition, in such series as show it, of any true affinity.
} 


\section{Bower.-Imperfect Sporangia in certain}

individual, they are not on that account to be accepted as of prior existence in the history of the race.

Of our four possible views which may be taken of imperfectly developed parts, we may now consider which is applicable to those imperfect sporangia which have been found at the base of a strobilus or fertile zone in various species of Lycopodium. In a sense they may be looked upon as nascent in the ontogeny, in so far as, starting from leaves which show no sign of sporangia at their base, we pass upwards to similar leaves presenting a sporangial rudiment, and on through successive phases of increasing size and sparing spore-production to the fully formed sporangium. Some deficiency of nutriment has probably determined their incomplete development in the lower region, but in the first stages of even the smallest rudiment the potentiality of complete development probably was once there, though not realized. Thus in a sense they may be styled nascent as regards the individual development. But are they to be looked upon as nascent in the phylogenetic sense? Does the progression from a minute vegetative papilla, through successive meagre stages of spore-production, to the fully formed sporangium, in any sense indicate the stages of actual evolution of the Lycopod sporangium ? This question must be answered in the negative. In the first place, the analogy with rudimentary stamens and pistils of Angiospermic flowers is obvious: in either case the rudimentary part is a mere parenchymatous papilla, which however occupies the correct position of the part which it represents. We must regard these imperfect sporangia as reduced rudiments, just as much as the abortive stamens of the Scrophulariaceae, or the abortive pistil of Lychnis dioica. And secondly, the whole weight of evolutionary probability is against the view that the progression in question is an upward progression : for these imperfect sporangia are present on fully developed sporophylls : in their simplest forms they bear 'the plain stamp of inutility ${ }^{1 '}$ : like other rudimentary. parts, they are highly variable ${ }^{2}$. The complete absence of

\footnotetext{
1 Origin of Species, chap. xiv, p. 397.
}

2 Ibid., p. I I 9. 
them in the vast majority of the leaves below the fertile zone may be explained on the general principle of economy, by which parts no longer functional are liable to obliteration ${ }^{1}$. On such grounds as these the opinion may be surely based that the imperfect sporangia at the base of the strobilus are vestigial organs, and not indicative of an upward evolution, leading in the race to the complete sporangium.

Goebel, in his Organographie ${ }^{2}$, has pointed out that 'we must, however, guard against considering all arrested organs as being descended from organs which were developed in the ancestors of existing forms.' He alludes to certain inflorescences, and remarks that it is 'quite a general rule that many more primordia of organs are formed than become functional.' In this matter I think that Lycopodium in its simple way is instructive. We find incompletely developed sporangia, both at the apex and the base of the strobilus (e.g. of L. imundatum), these, however similar in appearance, seem to have had a different phylogenetic history: For reasons already stated the basal sporangia may be held to be arrested, and vestigial as regards descent, and that in the ancestry they were represented by fully formed sporangia. But the series of successively smaller sporangia at the apex may be regarded as primordia of organs which may have never become functional in the ancestry: they are subtended by leaves of an arrested type, imperfect like the sporangia which they bear. And this is, indeed, the criterion by which such cases may be judged. Many apical buds, like those of Lycopodium, have an apparently unlimited power of forming primordia; but fail to mature them all: these rudiments might be described as phylogenetically nascent, or supernumerary; while sporangia or buds at the base of the fertile region would be properly regarded as phylogenetically evanescent,-as representing parts which in the history of the race had been accustomed to come to functional maturity. Thus in the case of Lycopodium we acquire the idea of a zone of reproductive activity, limited below by phylogenetically evanescent or

1 Origin of Species, chap. iv, p. I I 7 .

${ }^{2}$ Organography, Engl. ed., p. 60.

R 2 


\section{Bower.-Imperfect Sporangia in certain}

vestigial parts, above by phylogenetically nascent or supernumerary parts. Again, the comparison may be made with a Moss-sporogonium, and there also a fertile zone is found, with a vegetative region below : the series of cells of the archesporium is continued beyond the region of actual fertility both above and below: and the cells at the lower limit may similarly represent a phylogenetically evanescent archesporium, those at the upper limit a phylogenetically nascent region. As regards the succession of vegetative and reproductive phases, and their probable evolutionary origin in the sporophyte generation, the cases are alike ${ }^{1}$. What it is in such cases that determines where the limits of the fertile zone shall be is obscure; but the cause is doubtless related closely to nutrition ${ }^{1}$.

By comparison of living species of Lycopodium we see that the fertile zone is not always located at the same level of the plant as a whole: it is sometimes preceded by a shorter, sometimes by a longer vegetative region. An idea can thus be arrived at of the shifting of the fertile or spore-producing zone. The biological significance of this shifting is obvious, for any advance of the zone to a higher point by abortion of sporangia, while the sporophylls remain in a vegetative capacity only, provides a larger vegetative zone below for purposes of nutrition.

In most species of the undifferentiated Selago group, as in all the more specialized species of Lycopodium, there is a considerable basal region which is sterile. This region is however variable in length; indeed in some species of the Selagogroup, notably in L. compactum and Trencilla, sporangia are found quite down to the base of the mature plants; here then the whole of the mature plant is virtually a strobilus. Comparison of these extreme cases with those which show alternating sterile and fertile zones leads fairly to the conclusion,

\footnotetext{
1 Parallel examples might be quoted from the cones of Gymnosperms, and the inflorescences of many Angiosperms; but I prefer for the present to discuss only those simpler cases where the questions in hand are not complicated by high specialization.
} 
that the whole leafy plant in the mature state is potentially, as it is in these actually, fertile. Attention is then thrown back to embryonic plants, and the question arises, how early may the sporangia make their first appearance on the young sporophyte?

We have as yet no information as to the embryology of any of those extreme forms where sporangia are borne down to the base of the mature plant; and indeed of the whole Selago group, with its comparatively undifferentiated sporophyte, it is only in one species that the embryonic details have been observed, viz. in $L$. Selago. Bruchmann ${ }^{1}$ has given an account, with drawings, which supplies the facts. The prothalli of this species may be either buried in the soil, or superficial, in which latter case they may be deep green. But Bruchmann ${ }^{2}$ remarks that 'it appears to be of great advantage to the seedlings, which are not adapted for an underground growth, to arise as near to the surface of the soil as possible, so that their first leaves may easily reach the daylight.' This species then is not one of those specialized cases like $L$. clavatum $^{3}$, and $L$. annotinum, with deeply buried prothallus, but more nearly shares with $L$. cermum and $L$. inundatum what was probably the primitive state, viz. with a superficial, chlorophyll-containing prothallus. Bruchmann ${ }^{4}$ figured a large number of varying cases of the prothalli of this species, at different levels: some at the surface of the soil, others below, with their seedlings attached; and from these, together with his text, certain important facts emerge. The first period of development of the embryo, that is the initiation of the fundamental structure of the germ in L. Selago, corresponds to that in other species of the genus ${ }^{5}$ : but in VII.

${ }^{1}$ Ueber die Prothallien und die Keimpflanzen, \&c., Gotha, 1898, p. 97, Pl. VI,

${ }^{2}$ Loc. cit., p. 85 .

- For an additional description of the facts for $L$. clavatum, together with an excellent comparative discussion of the prothallus and embryo in other species, from the biological point of view, see W. H. Lang, Annals of Botany, vol. xiii, p. 279.
- Loc. cit., P1. VI, Figs. I-26.
5 Bruchmann, loc. cit., p. 98 . 


\section{Bower.-Imperfect Sporangia in certain}

the further development important differences from other European species arise, and the embryo in its later form resembles that of $L$. Phlegmaria. The foot remains small as a conical continuation of the large suspensor: there is no protocorm, nor are there any protophylls of the Phylloglossim type: the first leaves are green, and resemble the foliage leaves of the mature plant of $L$. Selago: these are carried up to the surface of the soil, whatever the position of the prothallus-buried or at the surface-by a proportional intercalary growth in the hypocotyl, which is directly continuous with the foot ${ }^{1}$ : the first root is formed near its base. The first branehing of the axis occurs in plants which have about six or seven developed leaves: 'after the second branching these seedlings may produce spores, while in other native species only quite old plants proceed to spore-development ${ }^{2}$ '. These characters, together with those of the sporophyte, are recognized by Bruchmann as showing that $L$. Selago is not near to any of the species native in Germany ${ }^{3}$.

Perhaps the most important of these facts is the early appearance of the sporangia on the seedling of L. Selago. It shows, in the only species of the Selago group yet examined embryologically, that early spore-production goes along with the undifferentiated condition of the whole plant. The stele also of the mature plant is of simpler structure, and probably more primitive type than those of other species whose embryology and anatomy are both known. These characters together indicate the primitive nature of the group, and suggest the further question, is the embryology also of $L$. Selago to be regarded as a primitive type, compared with that of other Lycopods, and if so what will the effect be on our views regarding Phylloglossum and the theory of the protocorm?

Before Treub's paper in which this term was introduced, and the theory of the protocorm enunciated ${ }^{4}$, the 'embryonic

1 Bruchmann, loc. cit., P1. VI, Figs. I-26, and Pl. VII, Figs. $4^{\mathrm{I}-43}$.

2 Ib., p. I00, and Pl. VI, Figs. 26-27.

${ }^{4}$ Buitenzorg, Annals, vol. viii, p. I. 
tubercle' recognized in $L$. cernunm was regarded as a foot, which had escaped from the prothallus : it is still spoken of by Bruchmann ${ }^{1}$ in that way, and the type of embryo of $L$. inundatum is described as 'freifüssig,' in which the embryonic foot is developed outside the prothallus. But Treub showed that the embryonic tubercle is not of the same origin as the intra-prothallial foot: the latter originates from the first or lower tier of the embryo, the tubercle from the upper, which gives rise also to the cotyledon and stem. The embryonic tubercle, thus shown by origin not to be the true foot, was regarded by Treub as an organ which played an important part in the passage of the sporophyte to a state of physiological independence. He regards it as a primitive, not a reduced structure, and introduced the term 'protocorm,' recognizing in it a preliminary stage of development of the young Lycopod plant. Those cases in which no obvious protocorm is developed are explained on the ground of its disappearance, and because of their epiphytic saprophytism (L. Phlegmaria, carinatum, Hippuris, nummularifolium) they are held to be more recent types than those which show a protocorm. Naturally in Phylloglossum the tuber itself is regarded as a protocorm, repeated over and over again, and on Treub's theory of the protocorm it would thus take a place as an embryonic type still playing a considerable rôle.

But now the question is, How will the embryology of $L$. Selago fall in with this view? It is a ground-growing species, in which neither the prothallus nor the sporophyte are highly specialized. But the protocorm is absent, there being no swelling at the base of the hypocotyl until the appearance of the first root. These facts seem to me to necessitate a reconsideration of the protocorm and protophylls: are they really primitive structures, general in the ancestry of all Lycopods, or the result of a vegetative adaptation, which has made its appearance in certain species only; formed early in the individual plant, but relatively late in the phylogeny; and not a general character for the whole race?

\footnotetext{
I Bruchmann, loc. cit., p. IO2.
} 
I think the latter view is the more probable one. It is apparent from the various memoirs on embryonic Lycopods that the initial plan of the embryo is essentially the same for all the species described; and that the differences depend upon different proportional development of the parts, and difference in the time of their first appearance. Where one part is largely developed at an early period, others are apt to be delayed, or to be developed on a smaller scale: in fact the principle of correlation holds in the embryo as elsewhere. As examples, in Phylloglossum (which may with propriety rank with the embryonic Lycopods) the large protocorm is formed before either protophylls, roots, or strobilus are initiated. In L. cernumm and imundatum the root and leafy shoot appear late, though the protocorm and protophylls which appear early are of relatively large size. In L. clavatum and annotinum the foot is very large and the axis early developed, but the first leaves are small and the first root appears rather late. On the other hand, in L. Selago, where no disproportionately large protocorm or foot is formed, axis and leaf are defined relatively early, and the root soon follows. Are then the protocorm or the specially enlarged foot really primitive parts of the embryo, or disturbing influences introduced only in special cases to meet special needs? Was it once universal in Lycopod embryos, and is it therefore necessary to explain by abortion the absence of such parenchymatous swellings in certain species ${ }^{1}$, and especially in $L$. Selago, which, as we have seen, shows in other respects

\footnotetext{
' Dr. Treub has quoted certain embryos of L. Phlegmaria, as showing what he regards as a rudimentary protocorm (Buit. Ann., viii, p. 32). In his paper on this species (Buit. Ann., v) he has shown on Pl. XXVI, in a series of embryos, a rounded swelling $(R)$, in the position in which the protocorm appears in the cernuum type: it may, under circumstances, form rhizoids (Fig. 4), but soon the true root forms at the apex of the protuberance. It is possible that this may be a rudimentary protocorm, but I do not think the facts conclusive; for the root appears exogenously just at the point of greatest convexity of the swelling; moreover, in L. cernuum, as in Phylloglossum, which have typical protocorms, the root does not appear on the tip of the protocorm (which would thus be its position if the swelling in L. Phlegmaria be really a protocorm), but in the upper region nearer the leaves.
} 
such primitive characters of the sporophyte? Taking into account the characters of its mature sporophyte both external and internal, I think we must regard $L$. Selago as primitive, and that it is so in the embryo as well as in the more mature sporophyte : its embryo quickly forms assimilating leaves, and its early nourishment is thus simply provided for, without the formation of any protocorm or protophylls.

The following considerations may help towards some alternative view of the protocorm and protophylls more in accordance with the fact of their absence in L. Selago, which on the above grounds we regard as a primitive species. The embryo Lycopod seems prone to parenchymatous swelling; two such swellings, somewhat similar in structure, but differing in place of origin and in function, are known, viz. the enlarged 'foot' of $L$. clavatum and annotinum, which originates from the lower tier of the embryo, and is intra-prothallial; and the protocorm of the cernuum type, which originates from the upper tier of the embryo, and is extra-prothallial. The former acts as an haustorium, the latter as a place of storage. A genus which shows two types of parenchymatous swelling in two distinct types of embryo, while both are absent from other species, cannot be expected to have ever had one of those as a constant feature in its ancestry. This consideration makes me doubt any general application of the theory of the protocorm in the genus Lycopodium. I should look upon these parenchymatous swellings, whether of the enlarged intra-prothallial foot or of the protocorm, as opportunist growths rather than as persistent relics constant in the ancestry. Phylloglossum, with its large protocorm, would then be the extreme type of a line of embryological specialization, not a form preserving the primitive embryological characters of the whole race ${ }^{1}$.

1 This discussion leads me back to a similar one written in $\mathbf{1 8 8 2}$, in a paper on Gnetum Gnemon (Q. J. Micr. Sci., xxii, p. 277), in which the conclusion was arrived at that the foot in vascular plants at large is not to be regarded as a clearly defined morphological member; it may rather be looked upon as a swelling of tissue, which arises only when and where required for the nutrition of the embryo. Doubtless in certain circles of affinity there is a degree of constancy in position and 


\section{Bower.-Imperfect Sporangia in certain}

In seeking to understand the nature of the protophylls it is a material fact that they are not sharply marked off from the typical foliage leaves: in embryos of the cermum type they merge gradually into the normal leaves, which in their turn pass on into sporophylls. And even in Phylloglossum, where usually the distinction is more marked, intermediate steps have been seen between the protophyll and the sporophyll. Another fact of importance is that protophylls are absent from some Lycopod embryos, and when present are only found on the protocorm. The relation of these parts, the protophyll and the protocorm, are evidently close; and as the protocorm may, on my view, be regarded as a special turgid development of the lower part of the stock, so the protophylls may be regarded as turgid types of leaf, the transitional forms to the normal foliage giving some idea of the steps of their specialization.

In the Lycopodineae we have thus three categories of leaf which merge into one another. We have seen that in the Selago type the sporophylls do not differ from the foliage leaves; that the first leaves of the Selago plantlet are normal foliage leaves; and that sporangia may be produced after the second branching of the young plant. It does not seem a strained interpretation of these facts that in Selago all the leaves from the first are potential sporophylls; but that those first formed are usually sterile by complete abortion of sporangia. We may then conceive the primitive embryo of Lycopodium as of the Selago type; with a hypocotyledonary stem which forms the first root near its base; with no protocorm nor protophylls, nor greatly enlarged foot; but connected by a suspensor and small foot with the prothallus, and its

origin of such haustorial structures, but the inconstancy in vascular plants at large prevents too precise generalization. Dr. Treub, referring to this question (Buit. Ann., v, p. I 30 ), remarks that my conclusion goes too far, in denying the morphological value of the foot in Vascular Cryptogams. But the further examples since described confirm me in the opinion. Goebel (Organographie, ii, p. 450) suggests that the term foot should be dropped, and haustorium substituted : this is a colourless term, which does not suggest any morphological identity for the parts included under it, but only physiological correspondence. On this ground the suggestion may be upheld. 
first leaves early exposed as assimilating leaves; these, however, do not differ in form from the early sporophylls with which they are probably homogeneous, though sterile by abortion of their sporangia. Starting from this prototype, the following modifications of the sporophyte are indicated by comparison of living species of Lycopodium. In those types with a protocorm (which are all more specialized sporophytes than Selago, having their sporangia formed later in the individual, and usually more strictly localized in strobili), the lowermost leaves, already sterile, have been developed as protophylls, which though appearing first in these individuals, would represent a relatively recent modification of leaf structure ${ }^{1}$. The fertile region, which is continuous in some species, is in most of the Selago group interrupted by irregular sterile zones, an arrangement which provides for more adequate nutrition, for which frequently a long sterile basal region precedes the fertile (sp. $6,7,3^{8}, 39$, \&c.). The sterile and fertile zones usually differ only in the absence or presence of sporangia, but there is, in some species of the Selago group (sp. 9, I 7, 39), evidence of a fining off of the sporophylls to smaller size than the sterile leaves, with the result of a partial definition of a fertile strobilus: this becomes more apparent in the sub-Selago group (sp. 42, 47, 49), but it is in the Lepidotis group that the strobilus becomes a definite terminal cone (sp. 5०, 52), though still liable to be interrupted (sp. 5I). In the Phlegmaria group the strobilus is marked off more sharply by the sporophylls being small; but still occasional sporangia may be found outside the strobilus (sp. 60), while leaves of the strobilus may be barren (sp. 6I, 67); the strobilus may also be continued into a shoot of the foliage type ; clearly the distinction of vegetative and fertile regions is not yet defined absolutely. But in the cernum group the definition is more exact. In the clavatum group of ground-growing forms again the strobilus is well

1 The terms 'protocorm' and 'protophyll ' may well be retained, but with the understanding that their priority is in the development of the parts of the individual, not of the race. 
defined, and certain members of the group illustrate a further specialization in accordance with their ground-habit, the strobilus being carried up on an elongated peduncle with small scale-leaves, an obviously useful device to secure a wider distribution of the spores. Another line of specialization results in the dorsiventral vegetative shoot, as in Selaginella, and this culminates in the climbing species, L. volubile, with its large and branched foliage system and clearly defined strobili. The whole genus shows in its living species the lines of specialization fairly indicated by gradual specific steps, starting from an undifferentiated strobilus, and attaining first a clear differentiation of the strobilus from the vegetative region: the latter may become in a high degree adapted to its environment; the former probably retains more truly the primitive condition of the whole shoot. Thus a comparison of the living species indicates that there has been a shifting onwards of the spore-producing zone and progressive intercalation of a vegetative zone, comparable to that indicated in the Mosses. In both series there is a strong physiological probability that such a differentiation should take place, as a nutritive advantage is gained, and in some cases the better provision for dispersal of the spores is secured; both advantages being the result of comparatively slight morphological changes.

The facts relating to partially or completely abortive sporangia in the genus Lycopodium are fairly intelligible, owing partly to the undifferentiated state of some of the species of the Selago group, partly to the considerable number of species in the genus. It is not to be expected that the matter will be as obvious in other Lycopodineae; still, abortive sporangia are found in other genera, which are susceptible of similar interpretation. Such examples as have been found will now be noted.

\section{SELAGINELLA.}

In this genus the strobili are definitely marked off from the vegetative region; no case of alternating sterile and fertile zones is recorded, but in some species the fertile spikes revert 
at the apex to a vegetative character. Abortive sporangia have been seen at the base of the strobilus in S. spinosa, P. B. ${ }^{1}$, and in S. Martensii, and would doubtless be found in many species $^{2}$, but no isolated sporangia have been seen in the sterile region.

The arrested sporangia at the base of the strobilus will bear the same interpretation as those in Lycopodium. Clearly the genus is in this, as in other respects, more specialized than Lycopodium.

\section{ISOETES.}

Wilson Smith ${ }^{3}$ has pointed out in the case of $I$. echinospora that the sterile leaves differ from the sporophylls in their smaller size. But a closer study of the sterile leaves almost always 'reveals the presence of aborted sporangia.' This observation led me to look over my old sections of Isoetes lacustris, with the result that sporangia in various degrees of abortion were found: in proportion as the spores are few in these, the sterile tissue is relatively bulky, but many of the sporangia remain quite small. Dissections showed that in the majority of leaves that are apparently sterile a rudimentary sporangium is really there, in the normal position.

Wilson Smith remarks further (1.c., 324) that 'the occurrence of aborted sporangia on so many of the sterile leaves shows that all the leaves are potentially sporophylls, and suggests the probability that Isoetes has retained a more primitive form than any other vascular plant.' This is clearly going too $\mathrm{far}^{4}$; but none the less the fact that most of the leaves show abortive sporangia is interesting in relation to the question in hand. The irregular recurrence of the sterile and fertile zones is similar to that seen in the Selago group of Lycopodium. It would be important to know how early

' Glück, Sporophyllmetamorphose, p. 355 .

${ }^{2}$ See Studies, i, Phil. Trans., 1894, p. 522 . I found them in all of the few species adequately examined.

3 Bot. Gaz., 1900, vol. xxix, p. 323.

4 Compare the remarks of Scott and Hill, Annals of Botany, vol. xiv, p. 443, \&c. 


\section{Bower.-Imperfect Sporangia in certain}

in the embryo the first traces of a sporangium may appear. They are certainly absent from the first-formed leaves of the young plant ${ }^{1}$.

\section{Psilotaceae.}

In Tmesipteris there is commonly a sterile region of some length at the base of the aerial shoot; in its upper part, fertile and sterile zones may alternate without any definite regularity. The zones are, however, excessively irregular in Tmesipteris; thus an odd synangium, or two or three, may be interpolated in a sterile region, or odd sterile leaves may occur in a region that is mostly fertile, a condition which has been found in some species of Lycopodium.

The length of the leaf does not depend upon the presence or absence of a synangium; fertile leaves often equal in length the sterile ones. But there is usually a general diminution of the size of the appendicular organs at the upper limit of the fertile region (especially where that region is long) which affects both organs alike. This condition resembles that of the less differentiated species of Lycopodium, of the Selago, and sub-Selago groups.

Arrested or imperfectly developed synangia are not uncommon, especially at the limits of the fertile zones ${ }^{2}$. They appear as small growths in the normal position on otherwise fully developed parts. They are susceptible of the same interpretation as the imperfect sporangia of Lycopodium.

In Psilotum the distribution of sterile and fertile regions resembles that in Tmesipteris, successive zones being found on the same branch, while the various branches of one shoot show a synchronism, in the limits being at the same levels in each; as is the case also in some of the Selago group of Lycopodium. Partially or completely abortive synangia are found especially about the limits of the fertile zones; and Solms-Laubach ${ }^{3}$ notes the intermediate types of leaf between

1 Campbell, Mosses and Ferns, Figs. I 49-I 53.

2 Bertrand, Arch. Bot. d. Nord, vol. i, p. 475 ; Bower, Phil. Trans., I 894, B., p. 544, and Pl. LII, Figs. I49-1 53 .

3 Solms-Laubach, Buit. Ann., vol. iv, p. I 74 . 
the simple and the double-bladed forms ; he remarks, however, that where they are more or less deeply cut or completely bifurcate there is almost always the rudiment of the synangium, initiated but not brought to full development, in the form of an outgrowth usually of brownish colour.

These facts for the Psilotaceae are plainly comparable with those in Lycopodium; and similar arguments might be based on them. But the case here cannot be so well appreciated, nor such clear conclusions drawn, owing to the fact that the group is isolated and represented by few living species; and secondly,-that the embryology is not known, while in the well-grown plants there is a long basal vegetative region before synangia first appear.

It is thus seen that abortive sporangia are found in all the genera of Lycopodineae, and, with the exception of Phylloglossum, at both the upper and lower limits of the fertile zone; often also within the fertile zone itself. The bearing of these facts has been so fully discussed for Lycopodium that no general application of them to the other genera need be repeated here, for the arguments and conclusions would be virtually the same.

\section{EQUiSETACEAE.}

In other Pteridophyta besides the Lycopodineae abortive spore-bearing organs are also found; for instance in the Equisetineae. Bearing in mind the Calamarian strobili, it may be an open question whether the annulus at the base of the strobilus of Equisetum is really a transitional body between the vegetative sheath and the sporangiophores (see Scott, Studies in Fossil Botany, p. 6I). But whatever view be taken on this point, the fact is that frequently smaller sporangiophores, with fewer sporangia, or even one only, may be found at the base of the strobilus; this is well seen in $E$. palustre. Sporangia may also be found on the annulus, and a good series was figured by Milde ${ }^{1}$, showing intermediate

1 Beiträge z. Kenntniss d. Equiseten (I85I), Pl. LV, Figs. 2I-38. 


\section{Bower.-Imperfect Sporangia in certain}

conditions between sporangiophores and teeth of the sheath. Ridley ${ }^{1}$ and Glück ${ }^{2}$ also have figured cases for E. Telmateja. I have a specimen of this species showing a number of isolated small sporangia on the annulus. Such examples at the base of the strobilus have probably a similar bearing to those incomplete sporangia at the base of the Lycopod strobilus. A further point for comparison is found in those frequent examples of continuation of the apex of the strobilus into a vegetative shoot ${ }^{3}$. This may be put in relation with the fossil Phyllotheca, which Solms describes as 'having its fertile spikes repeatedly interrupted by ordinary vegetative. whorls ${ }^{4}$.' Such facts tend to show that in the Equisetineae also the strobilus is not absolutely marked off from the vegetative region, while the proliferous Equiseta remind us of the Selago condition of Lycopodium. The facts are, however, not sufficiently distinctive to bear any considerable weight of argument, and some of the examples are plainly abnormalities.

\section{OPHIOGLOSSACEAE.}

In Ophioglossum vulgatum a rudimentary spike is often to be seen as a small peg-like growth in the place where a normal spike would be inserted. It is represented in Rabenhorst's Kryptogamen-Flora, iii, p. 537, Fig. I75 A. Similar abortive spikes have been seen in $O$. reticulatum and pendulum. Such cases show that leaves ostensibly sterile are potentially fertile. In Botrychirim Lunaria extraordinarily small plants are found to bear fertile leaves, with the fertile segment proportional to the sterile. But in some cases of small weak plants the fertile segment appears to be entirely absent. Here again the case is similar to that in Lycopodium; and it can hardly be doubted that frequently the leaves when apparently sterile were in their first steps potentially fertile;

3 Journal of Linn. Soc., vol. xx, p. 47.

${ }^{2}$ Glïck, Sporophyllmetamorphose: Flora, I895, P1. V, Figs. 4-6, Text, p. 364 .

${ }^{3}$ For most of the species a 'forma prolifera' has been described. See Milde, loc. cit. ; also Rabenhorst, Krypt.-Flora, iii ; see also Ridley, loc. cit.

4 Fossil Botany, English Ed., Oxford, p. 181, Fig. I7. 
in fact that here again potential fertility is more extensive than that which is realized. At least those leaves which bear undeveloped rudiments may be designated sterile sporophylls, and the imperfect spikes are to be regarded as vestigial, each being subtended not by imperfect, but by a fully developed sterile lamina ${ }^{1}$.

\section{Filicineae.}

In the larger leaved Pteridophyta examples of incompletely developed sporangia or sori are not uncommonly met with; but owing to their being distributed over the large leaf-area they are less susceptible of theoretical treatment than in the simpler cases of the smaller-leaved forms. Many instances of transition from sterile to fertile leaves, or parts of leaves, in Ferns have been described; the balance of vegetative and reproductive regions, even on the individual leaf, shows some interesting analogies with that on the whole plant in some species of Lycopodium. Glück ${ }^{2}$ has brought together a large number of such cases, intermediate between sterile and fertile leaves, which are so far interesting as they show the intimate relation of sterile and fertile leaves; developmentally it hardly needs to be reiterated that foliage leaves and sporophylls of Ferns are alike; the two types of leaf are merely variants of the same category of parts. Nor does it require to be stated again at the present day that in the individual the foliage leaves commonly precede the sporophylls. All the facts stated by Glück may be accepted as consistent with either the view that sporophylls are phylogenetically ' modified' foliage leaves, or that foliage leaves are sterile sporophylls. Stripped of all accessories, his conclusion, that all sporophylls are altered foliage leaves, is founded on the assumption that the development of the individual is a correct index of the evolution of the race, quite irrespective of the results of comparison. He arrives at an obvious ontogenetic conclusion, and states it as a phylogenetic truth.

1 Dr. Lang informs me that abortive fertile spikes are commonly found also in Helminthostachys, subtended in each case by a fully developed sterile lamina.

${ }^{2}$ Flora, 1895, Heft 2, pp. 322-355. 


\section{Bower.-Imperfect Sporangia in certain}

For comparison with those species of Lycopodium which are fertile to their base, it may be recalled that at least one Fern exists in which the leaves are all fertile. Prantl records 'the remarkable fact that in Lygodium subalatum, not only are normal leaves fertile to the very base, but also the sub-primordial leaves, and even the primordial leaves already bear sorophores. So that fully sterile leaves, or primary and secondary segments in this species are as yet unknown ${ }^{1}$.' Now it is to be noted that Lygodium belongs to a peculiarly ancient stock, which gives a special significance to the fact recorded by Prantl. And here it may be remembered that Prantl firmly held the idea of the priority of fertile over sterile leaves, and asserted it repeatedly ${ }^{2}$. Though no one would now subscribe to his comparison of the Hymenophyllaceous sorus with the Moss-sporogonium, his other points should not for that reason be discounted. But however correct his opinions may be, the evidence in the case of Ferns is likely to be less conclusive than for Lycopods. For it seems to be true that rudiments of sporangia are most frequently preserved where the sporangia are borne singly, and make an early appearance on the part which bears them, as in the Lycopods; while in the Ferns the sporangia are formed relatively late upon the sporophyll, and usually in large numbers.

And here I may remark that the Ferns should not be taken as a general guide to the morphology of other Pteridophytes; they are clearly a very specialized series, and on that account have not been put in the forefront of the present discussion. The argument derived from comparison of species of Lycopodium stands upon its own footing, and requires neither support nor check from comparison with the larger-leaved Filices, with which they have no near affinity.

\section{IMPERFECT SPORANGIA IN FOSSILS.}

The facts being as above stated for living species of Pteridophytes, the question arises whether there is any similar evidence from fossils. It may be said at once that the facts are scanty, and the arguments to be based on them inconclusive.

\footnotetext{
1 Schizaeaceae, p. I4.

2 Hymenophyllaceae, p. 62 ; Schizaeaceae, p. 6.
} 
In the genus Lycopodites, whatever errors may have been made in ascribing to it forms which are of other affinity ${ }^{1}$, there are certainly some specimens which show a habit very like some of our modern species of Lycopodium and Selaginella, and with their strobili but little differentiated from the vegetative region. Lycopodites ciliatus, Kidston ${ }^{2}$, from the middle coal measures, shows no clearly differentiated strobilus : the sporophylls are quite like those of Selaginella, with ciliate margin and broad base, subtending sporangia which are not radially elongated ; but there is no evidence of any alternating sterile and fertile zones, as in L. Selago. Mr. Kidston remarks that 'mixed with the leaves are macrospores of small size.' These are well seen, and of the zonated type : probably the plant was heterosporous, and may have been like a Selaginella with an ill-defined strobilus. Goldenberg ${ }^{3}$ distinguished two divisions of Lycopodites: 'Pananthites,' in which the sporangia are sessile in the axils of leaves not clearly differentiated from the foliage leaves, and 'Lepidotites,' those in which the sporangia are seated in terminal strobili. A good example of the latter is $L$. Stockii, Kidston, quoted by SolmsLaubach as having the habit of Lycopodium Phlegmaria ${ }^{4}$. These and other cases afford sufficient evidence that both of these types existed at least as early as the Middle Coal Measures. But as yet I know of no early evidence of the 'Selago' condition in them: it is to be remarked, however, that specimens of these small fossils are rare, and that they are easily overlooked.

Various Lepidostrobi, in which the strobilus is definitely limited, show imperfect sporangia towards the apex. In $L$. Brozenii I have observed and figured sporangia of small size towards the upper end of the strobilus ${ }^{5}$ : they contain no

${ }^{1}$ Fossil Botany, Solms-Laubach, Engl. Ed., p. 186.

${ }^{2}$ See Kidston, Trans. Nat. Hist. Soc., Glasgow, I90r, p. 37. Mr. Kidston has kindly shown me his specimen (No. ${ }^{7} 743$ ), upon which, together with his text, these notes are based.

${ }^{3}$ Flora Saraepontana Fossilis, 1 855, p. 9; see also Kidston, loc. cit., p. $3^{2}$.

4 Fossil Botany, Engl. Ed., p. 186.

${ }^{5}$ Studies, i, Phil. Trans., vol. 185 , p. 527, P1. XLVIII, Figs. 95, 99, I00. 
spores, and from their general characters seem to be arrested sporangia, rather than young ones in the normal course of development : but it is difficult to arrive at certainty on this point. The base of this cone is unfortunately incomplete. Dr. Scott quotes also a case of a Lepidostrobus in his own collection, in which the sporangia 'at the top are small, still closed, and with thick walls, showing that development has been arrested before the absorption of the inner layers.' 'I find the same thing,' he says, 'in my new cone, Lepidocarpon Lomaxi, as well as in a microsporangiate cone, which may probably belong to the same species ${ }^{1}$.' It seems more common to find the apex of the cone complete, than the base. One specimen in Mr. Kidston's collection (slide No. 98) of Lepidodendron Veltheimianum, from Pettycur, shows a gradual lessening of size of the sporangia towards the base, but no extreme reduction to vestigial proportions was observed. In Spencerites insignis ${ }^{2}$ a section of the cone 'which appears to have been made near one extremity of the strobilus,' shows some sporangia of small size: these have been re-examined and described by $\mathrm{S} \operatorname{cott}^{3}$, who, without being able to locate them at the apex or base of the cone, regards them as being 'abortive organs' the development of which has been 'arrested at a rather early stage.' In Sigillaria the cones, which are probably heterosporous, are usually borne on long pedicels: the bases of these strobili have been examined in a number of specimens in Mr. Kidston's collection: they show gradual transitions from the broad ciliated sporophylls, to the smaller, narrower basal bracts : there is no evidence of abortive sporangia, which indeed could hardly be expected in specimens which are all impressions. But the similarity in external appearance to large strobili of Lycopodium or Selaginella is sufficiently close to raise the impression that they probably existed.

Speaking of Calamostachys Binneyana, Williamson and

1 Extracts from a letter from Dr. Scott.

${ }^{2}$ Williamson, Fossil Plants of the Coal Measures, ix, Fig. 53, p. 34I.

3 'On Spencerites,' Phil. Trans., vol. clxxxix, B, I898, p. 93, Pl. XV, Fig. I5. 
Scott ${ }^{1}$ in discussing certain sporangia which are filled with parenchymatous tissue, express the opinion that they are ' more or less completely abortive sporangia.' But as their position in the strobilus is uncertain, they have no direct bearing on the question under discussion in this paper. And here may be mentioned that curious fossil Phyllotheca deliquescens, Goepp. ${ }^{2}$ : it seems uncertain what may be the true interpretation of it, though Solms speaks of the genus as differing from true Equisetaceae in having its fertile spikes repeatedly interrupted by ordinary vegetative leaf-whorls. This, however, cannot be closely compared with the 'Selago' condition of Lycopods.

Lastly, there is the case of Cheirostrobus: Scott, in his monograph on this fossil ${ }^{3}$, worked from two specimens: one probably a peduncle, the other a more complete cone. The latter shows clearly a reduction in size of the basal sporangia and sporophylls. This is well seen in the section figured as Scott's Photograph ${ }_{15}$, and drawing ${ }^{5}$, in which the lowest sporangium is barely one quarter the length of one of those at the middle of the cone: the whole outline of the cone is oval at the base, owing to the gradual diminution in length of the sporophylls and sporangiophores. On the peduncle ${ }^{4}$ the bases of the leaves or bracts are present, showing superior and inferior lobes: there is evidence, however, that the latter are smaller and simpler in structure than the corresponding lobes which are really fertile. As the foliage of the plant is unknown, it is impossible at present to base definite conclusions on these facts, beyond recognizing the reduction of the sporangia, and of the 'fertile segment,' at the base of the cone, and on the peduncle.

The general results to be drawn from these fragmentary facts from fossils are, that the strobili of fossils were not always definitely marked off from the vegetative region, and

1 Phil. Trans., I895, vol. clxxxṿ, B, p. 9 Io ; also Williamson, Phil. Trans., 1880, P1. XVI, Fig. I8.

${ }^{2}$ Solms-Laubach, Fossil Botany, Engl. Ed., p. 181, Fig. 17, B.

${ }^{3}$ Phil. Trans., vol. clxxxix, B (I897), p. I. 
that the strobili are, when defined, similar in their broad characters to those of modern times, showing diminution of sporangia at the apex, and also at the base. Though there is thus little conclusive evidence from such facts as have been brought forward relating to fossils, at least we may assert that, so far as it goes, it does not run counter to the results that have been obtained by comparison of living plants.

\section{General Conclusion.}

Abortive parts are not such prominent features in plants as in animals, and they have played a less important rôle in the theories of vegetable morphology than in those of comparative zoology. This is probably to be understood as a consequence of the continued embryology of plants, and the unlimited number of the appendicular parts, arising from their persistent meristems. Thus the initiation of individual parts, such as the reproductive organs of the sporophyte, may be deferred so late as to remove them far from the initial embryology of the plant. In animals, on the other hand, it is frequently the parts initiated early in the embryology which supply the best examples of vestigial organs.

But in the above pages we have seen that incompletely developed parts are frequent among the Pteridophyta. Such recurrent phenomena must not be ignored. Their treatment should be consistent with that of similar phenomena in other groups of plants, or in animals. And naturally we turn to the Phanerogams for guidance in morphological method, since in their comparative treatment abortive parts have been taken fully into account. It will be unnecessary to quote special instances of this, for the recognition of certain abortive parts as vestigial-that is representing parts which in the ancestry were once actually functional-is a common position in floral morphology. The ready acceptance of such conclusions for Flowering Plants is probably due to the fact that, in many cases, closely related genera and species allow of a complete and consecutive train of comparison, while also the arguments have for the most part dealt only with the parts of the flower, 
and have not touched the broader and more contentious question of the relations of the vegetative and reproductive parts.

On the other hand, as Goebel has pointed out, all incompletely developed parts are not to be assumed to represent parts which have been functional in the ancestry; and in dealing with the Pteridophytes, as also with Flowering Plants, we must distinguish between those parts which are really arrested and vestigial, and those which are simply supernumerary primordia. It is on a basis of comparison, combined with examination of the individual part, that this distinction can be drawn: such comparison in the large living genus, Lycopodium, has led to the view that the arrested sporangia at the base of a strobilus are really vestigial, while those at the apex may be simply supernumerary.

Perhaps for our present purpose the best analogy with this is to be found in Prantl's theory of the honey-leaves in the Ranunculaceae ${ }^{1}$. Prantl showed that the glandular honeyleaves are, on the grounds of form, position, and development, to be taken as stamens, which in place of forming pollen-sacs, developed usually as honey-secreting structures: they are in fact sterilized sporophylls. Their appearing prior to the stamens in the ontogeny does not prevent the floral morphologist from admitting their derivation by metamorphosis from stamens, which in their fully developed state are formed later in the individual flower. We may leave on one side for the present the wider question raised by Drude ${ }^{2}$ whether other parts of the flower also may not be metamorphosed stamens: on Prantl's theory of the honey-leaves an analogy is provided for us, which fits the present view for the sporophylls and sterile foliage leaves of Lycopodium: in both cases it is suggested that, by functional and structural modification, a series of parts differing in function from the original type has been intercalated: and that though these appear earlier in the individual, they were of later origin in the descent. It is thus attempted in this paper to apply to the strobiloid Pteridophyta the same method as is accepted in the morpho-

1 Engler's Jahrb., vol. ix, p. 225.

จ Schenk, Handbuch, iii, 2, p. 302. 


\section{Bower.-Imperfect Sporangia in certain}

logy of a family of Flowering Plants. And just as the honeyleaves may be altered stamens, so may the foliage-leaves of Lycopods be sterilized sporophylls.

But, conversely, we may turn for analogy to the Bryophyta. A comparative treatment of the sporogonium illustrates the progressive sterilization and intercalation of a vegetative phase between fertilization and spore-production. In the above pages the analogy has been pointed out between the balance of vegetative and reproductive phases in the sporogonium of certain Mosses and that in the Lycopods; and how in both series it may be recognized that there is a reproductive zone characterized at its lower limit by structural evidences of evanescent spore-development, and at its upper limit by evidences of nascent spore-production; in both regions the development being incomplete. The idea is thus presented of a fertile phase in the individual, which may in the descent move on to later phases in the individual, progressive sterilization taking place below, and progressive apical growth extending the plant above; with the result of an increasing vegetative system for nutrition. This analogy in the two large series should be allowed due comparative weight, and not discounted on the mere ground that the Bryophyta have a concrete archesporium and no appendages, while the Lycopods are leafy and bear separate sporangia. The lines of descent have probably been quite distinct; but the demands of nutrition, which dominated both, were alike.

The endeavour must be made to preserve a consistent morphological method for the Pteridophyta and for other plants both higher and lower in the scale. And to this end, just as much prominence should be given to the abortive parts which are present in the Pteridophyta, and especially in the simple Lycopods, as to the abortive parts in the Angiospermic flower: and they should be open to the same interpretation. On the other hand, the progressive sterilization admitted as an important factor in the progress of the Bryophyte sporogonium should equally be admitted, where the facts indicate it, in the upward progress of the Pteridophyta. 
Following then the methods of comparative study of Bryophytes and of Angiosperms, and employing them upon the results yielded by specific study of the genus Lycopodium, there seems only one reasonable reading of the facts: that sporangia, previously in the race fully formed, have become abortive; either partially, so as to leave vestigial traces, or entirely: that sporophylls have thus passed to the condition of foliage leaves: and that thereby the vegetative system has been increased. There seems further a reasonable probability that, in Lycopodium at least, the whole of the foliar system may have originated in this way ${ }^{1}$.

It was remarked above that the general line of argument in this paper would follow naturally, perhaps we may even say necessarily, from the acceptance of the theory of antithetic alternation. But it is also consistent with the view that the alternating generations are really homologous, if spore-production appeared early in the history of the neutral generation $^{2}$ : and this it must certainly have done, if the earliest sporophytes were like those simpler ones we see at the present day. Comparison leads decisively to the conclusion that the formation of spores was not a happy after-thought, imposed upon an already present and extensive vegetative system, but of early occurrence in the primitive individual. It may or

1 This idea has already been put forward by Naegeli in the following sentences (Abstammungslehre, p. 477): 'Die zweite Stufe ist also ein unverzweigter beblätterter Stengel; die noch höchst einfach gestalteten Blätter sind alle gleich und sporogonientragend : . . . in der Abstammungslinie der Lycopodiaceen mag diese Stufe grosse Aehnlichkeit mit einem unverzweigten Lycopodium Selago gehabt haben.' Though I should not subscribe to the exact mode of origin of such a form suggested by Naegeli, it is to be remarked that he clearly contemplated an organism in which all the leaves are originally sporophylls, and that the vegetative system originated by deferring the spore-production to later stages of the individual. The presence of the imperfect sporangia at the base of the fertile region in so many Lycopods supplies important evidence from vestigial organs, which coming after the enunciation of his views based on other grounds, is a very strong support of them.

${ }^{2}$ Compare Coulter, Origin of the leafy Sporophyte, Bot. Gaz., I899, p. 46. He suggests a possible antithetic origin in Bryophytes, and homologous for Pteridophytes; in the latter case he supposes a leafy axis bearing spores, derived from the thallus (p. 55). 
may not have antedated the whole vegetative system of the sporophyte, as the antithetic theory implies: but in any case spore-formation was of early date.

The theory of sterilization of sporophylls above stated for Lycopods embodies a tangible idea, which is in accordance with the facts, including those relating to abortive parts. It was met on a previous occasion by Prof. Goebel, first by a reference to large-leaved forms, and especially to his earlier observations on the sporophylls of Onoclea; but without reference to the detailed facts for Lycopodium, on which my argument was based ${ }^{1}$; subsequently by a simple 'non possumus'; and here again there was no reference to the facts relating to Lycopodium' ; nevertheless he remarks that 'Botany as a science is more concerned with facts than with phylogenetic theories.' He concludes, after a reference to Ferns, but still ignoring the Lycopods, that ' as to what occurred in prehistoric ages, we require far more convincing proofs than are afforded by the materials at present within our reach, before we can speak with any assurance.' It was met by Dr. Glück by the old assumption ${ }^{3}$, that the ontogeny is a key to the phylogeny: that because the foliage leaves are prior in the individual, therefore the later-formed sporophylls are altered foliage leaves. Readers may then choose between, first, the 'non possumus' position, which declines to entertain any phylogenetic theory on the point in question: I think this will not commend itself to inquiring minds, if they give attention to the facts which I have brought forward. Secondly, the position which assumes a prior vegetative system of the sporophyte, but gives no explanation how or when, in the descent, the spore-production, which is so constant a feature at the present day, came to be imposed upon it ${ }^{4}$. And thirdly a coherent

1 Annals of Botany, vi, I892, p. 359 .

2 Science Progress, iii, p. I 20.

Also Ber. d. d. Bot. Ges., I887, p. 69.

${ }^{3}$ Sporophyllmetamorphose, p. $3^{8} 3$.

4 Goebel wrote as follows on this point (Ber. d. d. Bot. Ges., p. 74): 'Die Pflanze bildet nur eine Art von Blattanlagen, und zwar Laubblattanlagen, von denen aber, infolge bestimmter Einwirkungen, regelmässig ein Theil zu Niederblättern, ein Theil zu Sporophyllen sich ausbildet, während die übrigen sich als Laubblätter weiter entwickeln.' 
hypothesis, which fairly meets the facts, and proceeds on the same methods with regard to vestigial organs as is adopted in floral morphology. Goebel, alluding to my previous paper, says that my views were based on 'phylogenetic grounds ${ }^{1}$.' These certainly came in, but the actual foundation was on the fact that incomplete sporangia exist at the base of the strobilus ${ }^{2}$. Whatever decision is now arrived at, it will have to take into account those imperfect sporangia at the base of the fertile region in Lycopods, and elsewhere, which, on grounds explained above, I regard as vestigial. If these are vestigial, then the position taken up in this paper is the natural consequence. If they are not vestigial, what are they?

Postscript.-Mr. Kidston, by letter, calls my attention to the case of Sphenophyllum majus, Bronn (see Kidston, Trans. Nat. Hist. Soc., Glasgow, vol. vi, p. 128), in which the cone is little modified in form from the ordinary foliage branch. The internodes are not shortened, and the bracts not more reduced in the limb than is seen in the segmented leaves of the ordinary foliage branches. Specimens of this fossil come from the Middle Coal Measures, and thus the similarity of the foliage shoot to the strobilus is seen in another fossil form of early date.

F. O. B.

1 Science Progress, iii, p. I 20.

2 See Studies, i, Phil. Trans., I 894, B, p. 535. 


\section{$2 \mathrm{BHL}$ Biodiversity Heritage Library}

Bower, F. O. 1901. "Imperfect sporangia in certain Pteridophytes. Are they vestigial?" Annals of botany 15, 225-267. https://doi.org/10.1093/oxfordjournals.aob.a088818.

View This Item Online: https://www.biodiversitylibrary.org/item/236929

DOI: https://doi.org/10.1093/oxfordjournals.aob.a088818

Permalink: https://www.biodiversitylibrary.org/partpdf/318622

\section{Holding Institution}

Smithsonian Libraries

\section{Sponsored by}

Biodiversity Heritage Library

\section{Copyright \& Reuse}

Copyright Status: Not in copyright. The BHL knows of no copyright restrictions on this item.

This document was created from content at the Biodiversity Heritage Library, the world's largest open access digital library for biodiversity literature and archives. Visit BHL at https://www.biodiversitylibrary.org. 